Volume 6 Issue 4, December 2019

Nationally Accredited Journal,

Decree No. B/4130/E5/E5.2.1/2019

\title{
The Role and Protection of Laws to Notary Related To the Dispute That Made Between the Parties
}

\author{
Monicha Rossalia Adigita ${ }^{1}$, Umar Ma'ruf ${ }^{2}$ and Aryani Witasari ${ }^{3}$
}

Abstract. The purpose of this study to determine and analyze: 1) Factors leading to disputes between the parties relating to the deed of Notary. 2) Role of relevant Notary Deed had made in the event of a dispute between the parties. 3) The legal protection against related Notary Deed which is made in the event of a dispute between the parties. Legally sociological research approach. The data in this study are primary data obtained from the field by means of interviews and secondary data consists of primary legal materials, secondary law and tertiary legal materials by means of literature. Data were then analyzed qualitatively.

Based on the results of data analysis can be concluded that: 1) Factors leading to disputes between the parties relating to Deed, there are two reasons, namely: breach of contract committed by one of the parties which resulted in the loss and not the acquisition of rights of one party and if the deed made by Notary goes wrong in terms of formal and material aspects of birth. 2) The role of the Notary in the event of any dispute if the dispute caused by the parties themselves then the Notary will not be involved and would only be called as a witness in the trial, but if notaries who made a mistake in making the deed of the Notary may be sued by the parties which would result be under the hand and null and void. The parties will also get compensation if the parties feel aggrieved by deed made by Notary. 3) Protection of the Notary Law contained in Article 66 of Law No. 22014 On Notary, wherein if the investigators, prosecutors and judges will perform a calling and examination of the Notary, must go through the approval of the Honorary Council of Notaries.

Keywords: Role and Legal Protection; Notarial Deed; Dispute

\section{Introduction}

Development of human life today, even more so in this increasingly modern world, many a dispute between private personal one with the other. This dispute arises when the "collision" between the interests of one man with another man. If a dispute occurs then the parties will make an effort so that the dispute can be resolved. Attempts to resolve a dispute there are two efforts that efforts to resolve through the court (litigation) as well as efforts court settlement (non-litigation). Existence of the certainty, order, and the protection of the law is the requirement of a written evidence with its authentic nature by knowing deeds, agreements, determination, and legal events, made before or by the competent authority, namely the Notary. ${ }^{4}$

Notary Definition contained in Article 1 paragraph 1 of Law No. 2 of 2014 on the Amendment of Act No. 30 of 2004 concerning Notary, which reads "Notary is a public official who is authorized to make the deed authentic and have the other authorities referred to in this Act or under the Act of others." In terms of daily notary is a person appointed by the government to make aka authentic or official deed. Notary is a public

\footnotetext{
${ }^{1}$ Notary office staff, email rossaliamonicha@gmail.com

2 Lecturer of Faculty of Law, Sultan Agung Islamic University Semarang

${ }^{3}$ Lecurer of Faculty of Law, Sultan Agung Islamic University Semarang

${ }^{4}$ Erika Kindyawati, Prija Djatmika, Nurini Aprilianda, Tanggung Jawab Notaris Dalam persekutuan Perdata Terhadap Pembuatan Akta, http://hukum.studentjournal.ub.ac.id/index.php/hukum/article/view/1384
} 
official, a public official if he be appointed and dismissed by the government and given the authority and obligation to serve the public in certain things. ${ }^{5}$ The development of public services also affected the increase in the services of a Notary. According to Habib Adjie, Notary office held or presence desired by the rule of law with a view to help and serve the people who need written evidence that is authentic about the circumstances, events or legal actions. With this basic as they are appointed as a Notary must have a passion to serve the community, and for the service, and appearing for the people who have felt serviced by notary in accordance with his duties, to give honorarium to the Notary. Therefore Notary does not mean anything if people do not need it. ${ }^{6}$ The layout of the significance of a Notary, that the Notary is authorized to make the deed containing the formal correctness in accordance with what was notified of the parties to the Notary, so it can be used as evidence in a legal dispute that is used to recall the events that have occurred, so it can be used for the purposes of proof. ${ }^{7}$ The authentic act is one means of written evidence in the form prescribed by law, made by or in the presence of officials / employees of public power for it in a place where the deed made, as the sound of the provisions of Article 1867 and 1868 Book of the Law Legal Civil. In the Civil Code regarding the principles of agreement, meaning that the legal agreement of the Civil Code was adhered to a principle that to deliver enough to agree any agreement and that the agreement and thus "engagement" thereof have been born on or seconds as mentioned above. ${ }^{9}$ According Herlien Boediono, in traffic relations of private law, Notary enjoy exclusive authority to make the deeds authentic. The authentic act against given strength strong evidence in cases of civil, so that a Notary is authorized to make the deeds authentic occupies a very important position in the life of the law. In many ways Notary serves as trusted advisor of people who need legal help, and the client can act as a direction ${ }^{10}$, The goal made written agreements before or Notary is that the deed be authentic act which can be used as evidence if one day there is a dispute between the parties or there is a lawsuit from the other party. ${ }^{11}$ Notaries in carrying out the functions and authority, a notary must act in an honest, thorough, independent, impartial, and safeguard the interests of those involved in the legal action. ${ }^{12}$ Notaries must provide services to the public in accordance with the legislation in force.

Practice what happened today many authentic deed of Notary disputed in court. This led to being called as a witness or Notary Public Notary even be sued in court. Based on the above, the authors are interested in doing research for the preparation of the study titled "The Role And Related Legal Protection Against Notary Deed What

\footnotetext{
${ }^{5}$ R. Soegondo Notodisoerjo,1993, Hukum Notariat Di Indonesia, Suatu Penjelasan, Jakarta: Raja Grafindo Persada, p. 44

${ }^{6}$ Habib Adjie, 2009, Sanksi Perdata dan Administratif Terhadap Notaris Sebagai Pejabat Publik, Second Edition, Bandung: Refika Aditama, p. 27

${ }^{7}$ Valentine Phebe Mowoka, Pelaksanaan Tanggung Jawab Notaris Terhadap Akta yang Dibuatnya, Lex et Societatis Journal article, Issue 4 Vol. II, 2014, p. 62

8 Herlien Boediono, 2013, Kumpulan Tulisan HUKUM PERDATA di Bidang Kenotariatan, Bandung: PT. Citra Aditya Bakti, p. 267

${ }^{9}$ Subekti, 1984, Aneka Perjanjian, Bandung: Alumni, p. 3

${ }^{10}$ Herlien Boediono, 2006, Asas Keseimbangan Bagi Hukum Perjanjian Indonesia, Hukum Perjanjian Berlandaskan Asas-Asas Wigati Indonesia, Bandung: Citra Aditya Bakti, p. 257

${ }^{11}$ Kunni Afifah, Tanggung Jawab dan Perlindungan Hukum bagi Notaris secara Perdata Terhadap Akta yang Dibuatnya, LEX Renaissance \# 1 Vol. January 2nd, 2017, p. 150

12 Umar Ma'ruf and Dony Wijaya, Tinjauan Hukum Kedudukan dan Fungsi Notaris Sebagai Pejabat Umum dalam Membuat Akta Otentik (Studi Kasus di Kecamatan Bergas Kabupaten Semaran), Jurnal Pembaharuan Hukum Volume II No. 2 Mei-Agustus 2015
} 
Volume 6 Issue 4, December 2019

Nationally Accredited Journal,

Decree No. B/4130/E5/E5.2.1/2019

Happens When he made Dispute Between the Parties."

\section{Research methods}

This research approach is legally sociological. Specifications descriptive analytical research. The data in this study are primary data obtained from the field by means of interviews and secondary data consists of primary legal materials, secondary law and tertiary legal materials by means of literature. Data were then analyzed qualitatively.

\section{Results and Discussion}

\subsection{Factors Why of Dispute Between Related Parties Deed.}

The parties in an agreement should qualify the validity of an agreement pursuant to Article 1320 of the Civil Code, namely: They agreed that bind himself; Ability to make a deal; A certain thing; and One reason kosher.

So that if the parties make an agreement and the agreement made by a competent authority, namely the Notary, it can be ascertained the validity of a treaty requirement in Article 1320 of the Civil Code have been met. But what happened today, many of the parties who neglect their obligations when the agreement has been valid certificate, so that there arose a dispute between the parties because one party feels aggrieved. "In a legal relationship and engagement always possible disputes between the parties that ultimately lead to disputes. Disputes can originate from a variety of sources of potential disputes. Can be a potential source of dispute border issues, natural resources, environmental degradation, trade, and others. "13

Notaries must ensure that what is delivered to him in matters relating to the authentic deed made, must be correct and in accordance with the will of the parties concerned. It can be expected in the event of a dispute Notaries are not dragged into the issue because the authentic deed already contained formal correctness that it was delivered by the parties to the Notary. But when the deed of Notary legal defects or errors made by notary deed intentionally or unintentionally, the Notary must give an account.

A dispute that occurred between the parties relating to this notarial deed can occur if a default among the parties themselves which resulted in one party does not get its due and when the Notary deed goes wrong in terms of formal and material aspects of birth.

Meanwhile, if found any false document in a deed authenticated by the Notary, to be proven whether Notary knowing and doing it on purpose or whether Notary not know. If he is convicted of the deliberate action then the Notary shall account for his actions. The legal consequences for an authentic deed of Notary by using forged documents, causing the deed down position into a deed under the hand and the deed can be canceled.

The parties to the deed can be in denial (or want to deny): ${ }^{14}$ Day, date, month and year of facing; Time (pm) is facing; Signature listed in the minutes of the deed; Felt never facing; The deed was not signed before the Notary; Deed not read; Another reason is based on the formality of the deed.

If the above proved the notarial deed will be transformed into a deed under the hand

\footnotetext{
${ }^{13}$ Adolf Huala Law, 2008, Hukum Penyelesaian Sengketa Internasional, Jakarta: Sinar Grafika, p. 1

${ }^{14}$ Pingkan Sundah, Tinjauan Yuridis Terhadap Tidak Dilaksanakannya Kewajiban Jabatan Notaris Menurut Undang-Undang No. 02 Tahun 2014, Lex et Societatis, Vol. II / No. 4 / May / 2014, p. 40
} 
and become null and void. And when the deed to cause damage to either party or parties who feel aggrieved then they can sue for damages against the Notary.

\subsection{Related Notary Deed role which he made Happens When Dispute Between the Parties}

Understanding Notary according to the Law of the Republic of Indonesia No. 2 of 2014 on the Amendment of the Law of the Republic of Indonesia No. 30 of 2004 About Notary Article 1, paragraph 1, Notary public official who is authorized to make an authentic deed and have more authority as referred to in this Act or under the Act other. Notaries in running the office has special rights or special. The privileges are associated with the right of refusal notaries who should be ignored, related behavior in terms of calling, examination, inquiry and investigation process. The principal function of a notary No 2, that notaries have the legal certainty to the public in any conduct binding-binding endorsement of the law,

Juridical basis of a Notary in his run to the Law of the Republic of Indonesia No. 2 of 2014 on the Amendment of the Law of the Republic of Indonesia No. 30 of 2004 About the Notary and the Law of the Republic of Indonesia No. 30 Year 2004 on Notary. "Notary to ensure certainty, order, and the protection of the law, it takes a written instrument that is authentic about deeds, agreements, determination, and legal events, made before or by the competent authority." ${ }^{15}$ Court must respect and recognize the content of the authentic act unless the parties deny can prove that a certain part of the deed have been replaced or that it is not approved by the parties. So if there is a dispute between the parties, then the efforts expected by way of kinship, but if a dispute is still unresolved, it can file a lawsuit or claim to the District Court.

The authentic act is an important evidence in the event of a dispute between the parties, so as Notary authorized to make such deed, a notary must ensure that the certificates were made to have the strength of evidence and provide legal certainty for the parties concerned. The strength of evidence on the certificate is considered valid if the procedures and terms of a deed in accordance with existing regulations. The role of the Notary in this case is very important, he must perform legal counseling in accordance with the interests and needs of the parties concerned in the deed. This is one of prevention in order to avoid future disputes. If the Notaries legal counseling is done can not be understood or even Notary of the parties may not perform well legal counseling it can lead to disputes in the future. Notaries who do not comply with applicable rules will be subject to civil and administrative sanctions. Administrative sanction in question is given a reprimand to dismissal of a Notary. Civil sanctions in question are authentic Notary deed will go down position into deed under the hand or even be null and void.

Disputes in a notarial deed because of two things: because the parties themselves if there is a breach of contract and Notary error in deed. If the dispute caused by the parties themselves and resolved litigation then the Notary will not be involved and would only be called as a witness in the trial, but if the parties choose the Notary as a mediator to resolve the dispute then in this position Notary should be a neutral party and does not favor one party, the task Notaries in case this only helps resolve and mediate between the parties and not the decision maker. Whereas in the case of notaries who made a mistake in making the Notary deed may be sued by the parties which would result be under the hand and null and void. The parties will also get compensation if the parties feel aggrieved by deed made by Notary.

${ }^{15}$ Widayati, Politik Hukum Kenotariatan, p. 5 
Volume 6 Issue 4, December 2019

Nationally Accredited Journal,

Decree No. B/4130/E5/E5.2.1/2019

\subsection{Legal Protection Against Related Notary Deed which he made Happens When Disputes Between Parties}

Notary as public officials are required to make an authentic deed authentic act according to the procedures and terms to be valid according to what is stipulated in the law. Notary so could avoid the various problems and disputes that might arise in the future, when the Notary deed has been made in accordance with the procedures and terms then certainly Notary can be freed from a wide variety of demands. Notaries must also comply with the Law Notary and Notary Code in order to avoid problems and sanctions.

With many problems and disputes that occur in the world of notaries, then it is possible if the Notary is reported on a deed made by the parties or other parties. So Notaries can be invoked by the police, prosecutors or judges, but by UUJN applicable to the Notary on Article 66 in order summoning the Notary by police, prosecutors or judges must go through the approval of the Supervisory Council of Regions. And if the police, prosecutors or judges directly call the Notary without the approval of the Regional Supervisory Council, the police, the prosecution or the judge violated the provisions of the Act.

The parties who feel aggrieved by the Notary must report to the Regional Supervisory Council or Notary Honorary Council because Article 67 paragraph 1 UUJN that the authorities overseeing the notary is a Minister, that the Minister of Justice and Human Rights. To conduct further scrutiny of the Minister of Justice and Human Rights form the Regional Supervisory Council in accordance with Article 67, paragraph 2 and 3 UUJN. It is intended that a Notary is not simply an issue for the parties in matters relating to the deed.

Notaries in running the office is bound by the oath of office stated in Article 4 Paragraph (2) of Law No. 2 of 2014 concerning Notary one of the rules is to keep the contents of the deed and the information obtained in the execution of his office. Understanding conceal the contents of the deed and the information obtained in carrying out the position, not only to not notify or disclose the contents of the deed he had done, but including also does not provide deed, a copy of the deed or citations deed and does not show the contents of the deed to anyone as set forth in Article 54 of Law No. 2 of 2014 concerning Notary, except to the parties interested in such deed, heirs and assigns of the deed. ${ }^{16}$

Besides notaries also have rights and obligations dissenter as stipulated in Article 16 Paragraph (1) letter (f), Article 322 of the Criminal Code, Article 170 of the Criminal Procedure Code, Article 1909 of the Civil Code, Article 146 HIR and Article 89 of Law No. 51 of 2009 on Administrative Courts. ${ }^{17}$

But this Notary right of refusal can be waived if he gets the approval of the Honorary Council of Notaries to give testimony, a copy of minutes of the deed, or the letters attached to the minutes of the deed to the investigators, prosecutors and judges. This is a form of legal protection for the Notary.

\section{Closing}

${ }^{16}$ https://www.kompasko.com/2018/11/perlindungan-hukum-terhadap-notaris.html, On 8 November 2019 at $20: 27$

17 ibid 


\subsection{Conclusion}

Based on the results of the above discussion it concluded:

- Factors that cause disputes between the parties relating to Deed, there are two reasons, namely: breach of contract committed by one of the parties which resulted in the loss and not the acquisition of rights of one party and if the deed made by Notary errors are made in terms of aspects of birth formal and material.

- The role of the Notary in the event of any dispute if the dispute caused by the parties themselves then the Notary will not be involved and would only be called as a witness in the trial, but if notaries who made a mistake in making the deed of the Notary may be sued by the parties which would result be in under hand and null and void. The parties will also get compensation if the parties feel aggrieved by deed made by Notary.

- Legal Protection for Notary contained in Article 66 of Law No. 22014 On Notary, wherein if the investigators, prosecutors and judges will perform a calling and examination of the Notary, must go through the approval of the Honorary Council of Notaries

\subsection{Suggestion}

Notary as a public official should be able to create a certificate that can be narrowed or prevent any dispute between the parties conducted due to breach or due to errors in the birth of a notary deed, so that all parties still perform its obligations until the agreement expires and is not detrimental to either party.

\section{References}

[1] Erika Kindyawati, Prija Djatmika, Nurini Aprilianda, Tanggung Jawab Notaris Dalam persekutuan Perdata Terhadap Pembuatan Akta, http://hukum.studentjournal.ub.ac.id/index.php/hukum/article/view/1384

[2] Habib Adjie,2009, Sanksi Perdata dan Administratif Terhadap Notaris Sebagai Pejabat Publik, Second Edition, Bandung: Refika Aditama

[3] Herlien Boediono, 2006, Asas Keseimbangan Bagi Hukum Perjanjian Indonesia, Hukum Perjanjian Berlandaskan Asas-Asas Wigati Indonesia, Bandung: Citra Aditya Bakti

[4] Herlien Boedion, 2013, Kumpulan Tulisan HUKUM PERDATA di Bidang Kenotariatan, PT. Citra Aditya Bakti, Bandung: PT. Citra Aditya Bakti

[5] Adolf Huala, 2008, Hukum Penyelesaian Sengketa Internasional, Jakarta: Sinar Grafika

[6] Kunni Afifah, Tanggung Jawab dan Perlindungan Hukum bagi Notaris secara Perdata Terhadap Akta yang Dibuatnya, LEX Renaissance \# 1 Vol. January 2nd, 2017

[7] Pingkan Sundah, Tinjauan Yuridis Terhadap Tidak Dilaksanakannya Kewajiban Jabatan Notaris Menurut Undang-Undang No. 02 Tahun 2014, Lex et Societatis, Vol. II / No. 4 / May / 2014

[8] R. Soegondo Notodisoerjo,1993, Hukum Notariat Di Indonesia, Suatu Penjelasan, Jakarta: Raja Grafindo Persada

[9] Subekti, 1984, Aneka Perjanjian, Bandung: Alumni

[10] Umar Ma'Ruf and Dony Wijaya, Tinjauan Hukum Kedudukan dan Fungsi Notaris Sebagai Pejabat Umum dalam Membuat Akta Otentik (Studi Kasus di Kecamatan Bergas Kabupaten Semaran, Journal of Law Reform Volume II \# May 2nd-August 2015

[11] Valentine Phebe Mowoka, Pelaksanaa Tanggung Jawab Notaris Terhadap Akta yang Dibuatnya, Lex et Societatis Journal article, Issue 4 Vol. II, 2014 